\title{
Bicaudal-C spatially controls translation of vertebrate maternal mRNAs
}

\author{
YAN ZHANG, ${ }^{1,4,5}$ AMY COOKE, ${ }^{2,4,6}$ SOOKHEE PARK, ${ }^{1}$ COLIN N. DEWEY, ${ }^{3}$ MARVIN WICKENS, ${ }^{2}$ and MICHAEL \\ D. SHEETS ${ }^{1,7}$ \\ ${ }^{1}$ Department of Biomolecular Chemistry, School of Medicine and Public Health, ${ }^{2}$ Department of Biochemistry, College of Agricultural and Life \\ Sciences, ${ }^{3}$ Department of Biostatistics and Medical Informatics, School of Medicine and Public Health, University of Wisconsin-Madison, Madison, \\ Wisconsin 53706, USA
}

\begin{abstract}
The Xenopus Cripto-1 protein is confined to the cells of the animal hemisphere during early embryogenesis where it regulates the formation of anterior structures. Cripto-1 protein accumulates only in animal cells because cripto- 1 mRNA in cells of the vegetal hemisphere is translationally repressed. Here, we show that the RNA binding protein, Bicaudal-C (Bic-C), functioned directly in this vegetal cell-specific repression. While Bic- $\mathrm{C}$ protein is normally confined to vegetal cells, ectopic expression of Bic-C in animal cells repressed a cripto-1 mRNA reporter and associated with endogenous cripto-1 mRNA. Repression by Bic-C required its N-terminal domain, comprised of multiple $\mathrm{KH}$ motifs, for specific binding to relevant control elements within the cripto-1 mRNA and a functionally separable C-terminal translation repression domain. Bic-C-mediated repression required the $5^{\prime}$ CAP and translation initiation factors, but not a poly(A) tail or the conserved SAM domain within Bic-C. Bic-C-directed immunoprecipitation followed by deep sequencing of associated mRNAs identified multiple Bic-C-regulated mRNA targets, including cripto-1 mRNA, providing new insights and tools for understanding the role of Bic-C in vertebrate development.
\end{abstract}

Keywords: Bicaudal-C; maternal mRNAs; translation; Xenopus

\section{INTRODUCTION}

Bicaudal-C (Bic-C) RNA binding proteins have vital roles in vertebrate embryogenesis and also in adult tissues, including the kidney, heart, and pancreas (Saffman et al. 1998; Chicoine et al. 2007; Gamberi and Lasko 2012). For example, Bic-C mutant mice develop renal cysts, providing a model for polycystic kidney disease (Maisonneuve et al. 2009; Tran et al. 2010). In Drosophila, where Bic-C was first identified, Bic-C contributes to patterning of the early embryo by repressing specific maternal mRNAs, such as oskar (Saffman et al. 1998; Chicoine et al. 2007). However, in vertebrates the mechanisms of Bic-C action have not been identified nor have mRNA targets been identified systematically.

Translation of the Cripto-1 mRNA (also referred to as $\mathrm{xCR} 1)$ in Xenopus laevis embryos is confined to the cells of the animal hemisphere (Zhang et al. 2009). This finding explains why $x$ CR1 protein accumulates only within the animal cells even though $\mathrm{xCR} 1 \mathrm{mRNAs}$ are equally distributed in cells

${ }^{4}$ These authors contributed equally to this work.

Present addresses: ${ }^{5}$ Department of Molecular Biosciences, Northwestern University, Evanston, IL 60208-3500, USA; ${ }^{6}$ EMBL Heidelberg, 69117 Heidelberg, Germany

${ }^{7}$ Corresponding author

E-mail mdsheets@wisc.edu

Article published online ahead of print. Article and publication date are at http://www.rnajournal.org/cgi/doi/10.1261/rna.041665.113. of both the animal and vegetal hemispheres (Dorey and Hill 2006). More specifically, we demonstrated that this spatial regulation was achieved by a vegetal cell-specific translational repression mechanism that functioned through specific elements of the xCR1 mRNA 3' UTR (Zhang et al. 2009). This spatial control of $\mathrm{xCR} 1$ translation is consistent with the fact that $\mathrm{xCR} 1$ is required for the formation of the anterior nervous system and other structures of the head that develop from cells of the animal hemisphere (Yabe et al. 2003; Tao et al. 2005). Thus, defining the mechanistic basis of spatially controlled xCR1 mRNA translation is important for understanding normal vertebrate embryogenesis.

Here, we show that Xenopus Bic-C RNA binding protein is the key determinant of xCR1 mRNA's spatially regulated translation and functions directly through a regulatory element, called the TCE (translational control element), within xCR1 mRNA's 3' UTR. Bic-C repression was mediated via separable RNA-binding and effector (repression) domains and, unexpectedly, the Bic-C SAM domain was not essential for repression. Repression was cap- and initiation factor-dependent but poly(A)-independent. Bic-C-directed immunoprecipi-

(C) 2013 Zhang et al. This article is distributed exclusively by the RNA Society for the first 12 months after the full-issue publication date (see http://rnajournal.cshlp.org/site/misc/terms.xhtml). After 12 months, it is available under a Creative Commons License (Attribution-NonCommercial 3.0 Unported), as described at http://creativecommons.org/licenses/by-nc/3.0/. 
tation followed by deep sequencing of associated mRNAs revealed many previously unknown Bic-C mRNA targets, several of which, including xCR1 mRNA, encode proteins that have been implicated in developmentally important processes such as the Nodal/TGF $\beta$ and Wnt pathways. We conclude that Bic-C functions to influence cell-fate decisions and create embryonic polarities during the maternally controlled stages of vertebrate embryogenesis by direct translational regulation of mRNAs that encode key cell-fate determinants.

\section{RESULTS}

\section{Bic-C repressed xCR1 $\mathrm{mRNA}$ translation when ectopically expressed in cells of the animal hemisphere}

While the Xenopus xCR1 mRNA is distributed throughout all cells of the embryo, only xCR 1 mRNA present in animal cells is translated (Dorey and Hill 2006; Zhang et al. 2009). Our previous study demonstrated the existence of a repression mechanism in cells of the vegetal hemisphere that prevents $\mathrm{xCR} 1$ mRNA translation (Zhang et al. 2009). To address the mechanism of vegetal-cell repression, we examined the possible role of two known RNA regulatory proteins that are encoded by maternal mRNAs that are themselves localized to vegetal cells_-Bicaudal-C (Bic-C) (Wessely and De Robertis 2000) and Nanos1 (previously Xcat2) (Mosquera et al. 1993). We reasoned that if Bic-C and/or Nanos1 were responsible for repression of xCR 1 mRNA translation in vegetal cells, then their ectopic expression in animal cells might be able to repress xCR1 mRNA translation in those cells. Therefore, mRNAs encoding Bic-C and Nanos1 were injected into animal cells of eight-cell Xenopus embryos together with a luciferase reporter
mRNA containing the $3^{\prime}$ UTR of $x C R 1$ mRNA that is sufficient for vegetal-cell repression (Fig. 1A; Zhang et al. 2009). Repression was quantified as the ratio of luciferase activity observed with the candidate repressor to that obtained without it.

Ectopic Bic-C repressed translation of the Luc-xCR1 reporter mRNA, while Nanos1 did not (Fig. 1B). Both Bic-C and Nanos1 proteins were expressed, as measured by immunoblotting (Supplemental Fig. 1A). Repression required elements within the $\mathrm{xCR} 13^{\prime}$ UTR, as a cyclin B1 3'-UTR reporter was unaffected (Fig. 1B; Sheets et al. 1994). Levels of both reporter mRNAs were unaffected by Bic-C; thus, Bic$\mathrm{C}$ did not cause mRNA decay (Supplemental Fig. 1B,C).

To identify RNA sequences required to direct repression by Bic- $\mathrm{C}$ in animal cells, we analyzed reporters bearing different segments of the $\mathrm{xCR} 13^{\prime}$ UTR in the ectopic repression assay. A central region of the $\mathrm{xCR} 1 \mathrm{mRNA} 3^{\prime}$ UTR, termed the TCE (nt 286-637) (Zhang et al. 2009), was essential for repression in animal cells: reporters carrying the TCE were repressed by Bic-C, while reporters bearing the $3^{\prime}$-UTR regions to its $5^{\prime}$ (nt 1-308) or 3' (nt 615-941) sides were not (Fig. 1C). Additional control reporters, each with a different $3^{\prime}$ UTR, were insensitive to Bic-C (Supplemental Fig. 1D). These data identify a repressive element that responds to Bic- $\mathrm{C}$ in animal cells. That same element also mediates repression by endogenous factors in vegetal cells (Zhang et al. 2009).

\section{Bic-C-mediated translation repression operated through the translation-initiation complex}

In our previous study of xCR1 mRNA translation, we showed that the $\mathrm{xCR} 13^{\prime}$ UTR directed vegetal-cell repression through a mechanism that required the $5^{\prime}$ cap and initiation factors
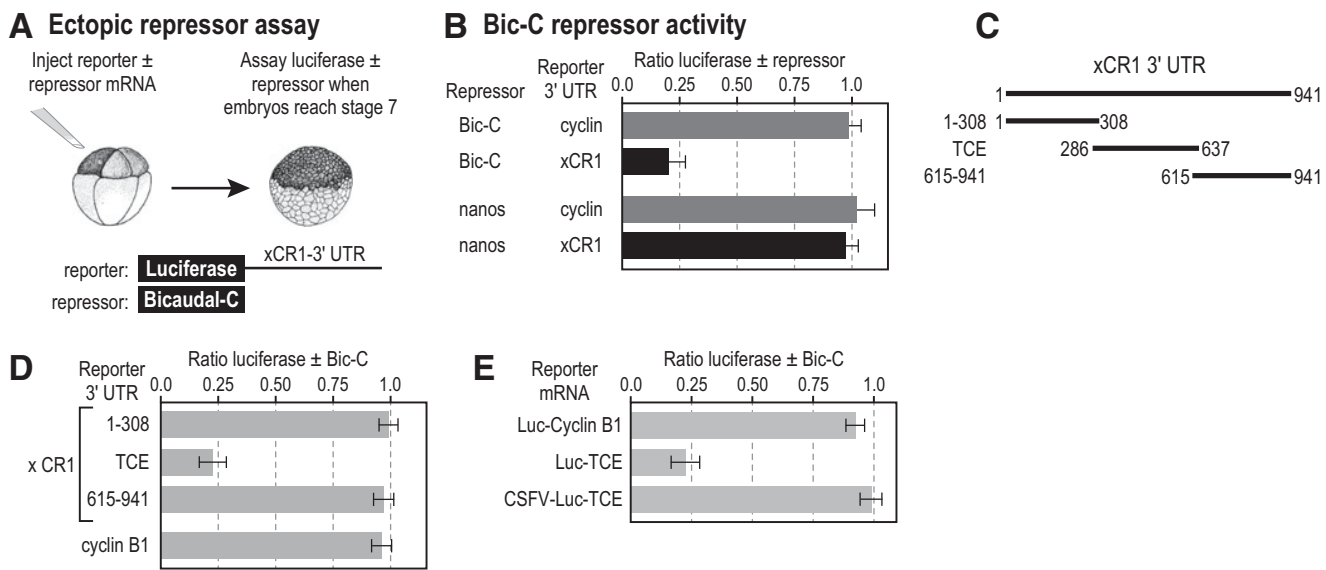

FIGURE 1. xCR1 mRNA translation can be repressed by Bicaudal-C. (A) Diagram of repression assay. Luciferase reporter mRNAs Luc/xCR1 (contains the $3^{\prime}$ UTR of the xCR1 mRNA) or Luc/Cyclin-BI (contains the 3' UTR of the cyclinB1 mRNA) were injected into Xenopus embryos with or without the mRNA encoding candidate repressors (HA-Bic-C or MYC-Nanos1). Injected embryos were assayed for luciferase (Sheets et al. 1994; Fritz and Sheets 2001; Zhang et al. 2009), and the ratio of luciferase with and without a putative repressor was calculated as a measure of repression. (B) Bic-C specifically repressed the Luc/xCR1 reporter mRNA. (C,D) Regions of the xCR1 3' UTR used in luciferase reporter mRNAs. The TCE (translational control element) was previously referred to as the Mut2 region (Zhang et al. 2009) and shown to be sufficient for repression in vegetal cells. Reporter mRNAs were analyzed for repression by Bic-C as described in $A$ and $B$. (E) Repression by Bicaudal-C required a $5^{\prime}$ cap. The CSFV-Luc/xCR1TCE reporter mRNAs contain the IRES from the CSFV $5^{\prime}$ of the luciferase coding region and the TCE of the xCR $13^{\prime}$ UTR. The reporter mRNAs were analyzed for repression by Bic-C as described in $A$ and $B$. 
eIF4F and eIF3. To begin to discern Bic-C's mechanism of action, we analyzed reporter RNAs bearing an ApppG cap and the CSFV IRES in animal cells of Xenopus embryos expressing Bic-C (Fig. 1E). The ApppG cap prevents cap-dependent translation, while the CSFV IRES bypasses the requirement for the initiation factors eIF4F and eIF3 (Otero et al. 2001; Kieft 2008). The CSFV IRES abolished Bic-C-mediated repression (Fig. 1E). Thus, Bic-C-dependent repression, as measured in the animal cell repression assay, recapitulated the vegetal-cell repression mechanism mediated through the xCR1 $3^{\prime}$ UTR in terms of its dependence on the normal $5^{\prime}$ mRNA translation initiation complex.

The C-terminal region of vertebrate Bic-C possessed the repressive activity that functioned independent of a $3^{\prime}$ poly(A) tail

The protein domains essential for the translational repressor functions of Bic-C are unknown in any organism. To identify repression domains in Bic-C, we tethered segments of Bic-C to reporter mRNAs via MS2 coat protein (Coller et al. 1998; Coller and Wickens 2007). SinceMS2 protein provides the RNA binding activity, repression can be assayed independent of Bic-C's own RNA binding activity (Fig. 2A-C). We analyzed different segments of Bic-C as MS2-fusion proteins: the $\mathrm{N}$-terminal half $(\mathrm{N}$-term) that is comprised of multiple hnRNP-K-homolog $(\mathrm{KH})$ domains, which are recognized RNA binding modules, the C-terminal half (C-term) that includes the sterile alpha motif (SAM) domain, the C-terminal half lacking the SAM domain (C-term $\triangle \mathrm{SAM}$ ), and finally the isolated SAM domain (Fig. 2A). Only the C-terminal portion of Bic-C repressed the reporter as efficiently as full-length BicC (Fig. 2C). The C-terminal region lacking the SAM domain (C-term $\triangle \mathrm{SAM}$ ) also repressed translation, albeit less efficiently. The $\mathrm{N}$-terminal half and the isolated SAM domain exhibited no repression activity. We conclude that the Cterminal region of Bic-C outside of the SAM domain possesses repression activity, while the SAM domain contributes to but is not sufficient for repression. This region of Bic-C, which lacks similarity to known protein domains, exhibits $>50 \%$ amino acid identity among vertebrate Bic-C proteins (Gamberi and Lasko 2012).

Translational repression by Drosophila Bic- $\mathrm{C}$ requires that the target mRNA possess a $3^{\prime}$ poly(A) tail (Chicoine et al. 2007). However, in our previous study, vegetal-cell repression of $\mathrm{xCR} 1 \mathrm{mRNA}$ was poly(A) tail-independent (Zhang et al. 2009). These data suggest that vertebrate Bic-C-mediated repression is different from that in Drosophila in that it does not require the presence of a poly(A) tail on the target mRNA. Therefore, we compared Bic-C reporter mRNA repression targets that differed only in terms of containing or lacking a poly(A) tail in the tethered translation assay (Fig. 2C). Bic$\mathrm{C}$-dependent repression occurred efficiently regardless of whether the target mRNA contained a poly(A) tail. In addition, a human MS2-C-term-Bic-C fusion protein behaved
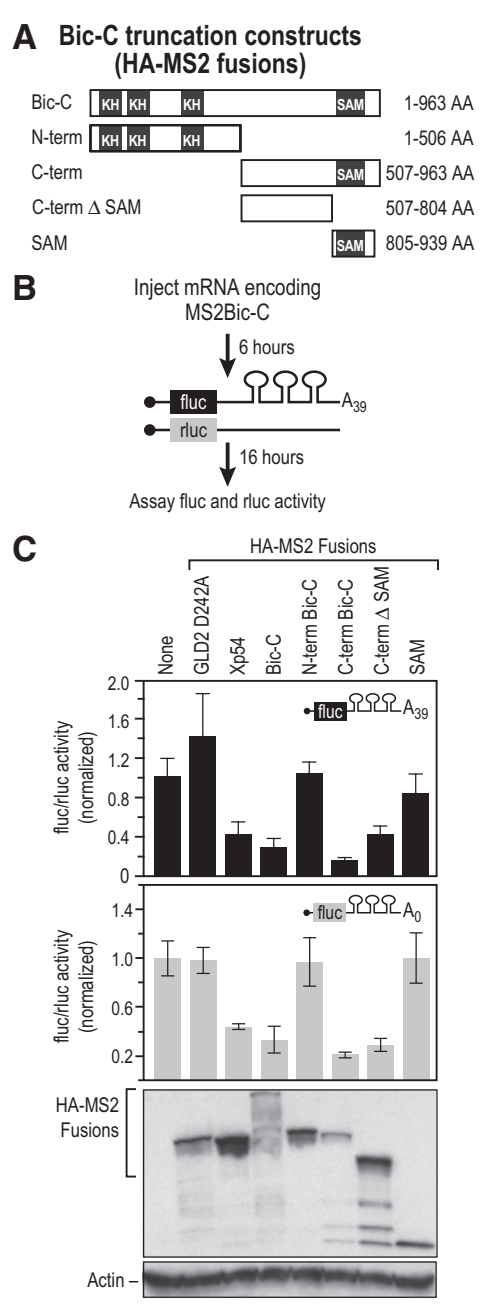

FIGURE 2. The C-terminal region of Bic- $\mathrm{C}$ contains translational repression activity. (A) The regions of Bic-C fused to MS2. (B) Diagram of the tethered translation assay (Coller et al. 1998; Coller and Wickens 2002, 2007). mRNAs encoding different Bic-C MS2 fusions were injected into oocytes, followed by injection of two reporter mRNAs; the 3' UTR of the firefly luciferase reporter mRNA contained three MS2-binding sites and a 39-nt poly(A) tail; the Renilla luciferase reporter mRNA lacked MS2 sites. $(C)$ The C-terminal half of Bic-C repressed translation independent of poly(A). Top panel: relative repression of firefly luciferase poly A39 mRNA translation by each protein. Middle panel: translational repression of firefly luciferase mRNA lacking a poly(A) tail by each protein. Bottom panel: analysis of fusion protein expression by immunoblotting with $\alpha-\mathrm{HA}$ and $\alpha$-actin antibodies.

similarly to the Xenopus MS2-C-term-Bic-C fusion protein in these experiments (Supplemental Fig. 2). We conclude that Bic-C-mediated translational repression in vertebrates does not require that the target mRNA contain a poly(A) tail.

\section{The N-terminal region of Bic-C bound the same region of $3^{\prime}$-UTR mRNA that was required for translational repression of XCR1 mRNA}

The N-terminal region of Xenopus Bic-C is comprised of multiple $\mathrm{KH}$ domains, which often mediate protein-RNA interactions (Wessely and De Robertis 2000; Valverde et al. 2008; 
Gamberi and Lasko 2012; Muller-McNicoll and Neugebauer 2013). To determine whether Bic-C bound RNA elements within the $\mathrm{xCR} 13^{\prime}$ UTR directly, we measured the interaction between recombinant Bic-C protein and various RNA substrates in vitro. We purified bacterially expressed protein that comprised the N-terminus of Bic-C, including the $\mathrm{KH}$ domains (aa 1-506), as a GST fusion protein (N-Bic-C). In electrophoretic mobility shift assays, the $\mathrm{N}$-Bic-C protein bound a radiolabeled RNA consisting of the TCE, the RNA element mediating repression by Bic-C in animal cells (Fig. 1B), and the same RNA region required to mediate vegetal-cell repression of $\mathrm{xCR} 1 \mathrm{mRNA}$ reporters in vivo (Fig. 3A; Zhang et al. 2009). In contrast, RNAs from the $5^{\prime}$ or $3^{\prime}$ side of the TCE (Fig. 3A, 1-308 RNA, lanes 1-3 and 615-941 RNA, lanes 7-9) or a control RNA lacking xCR1 mRNA 3'-UTR sequences (Fig. 3A, lanes 10-12) were bound only weakly by N-Bic-C. We conclude that the $\mathrm{N}$-terminal region of Bic-C contains the

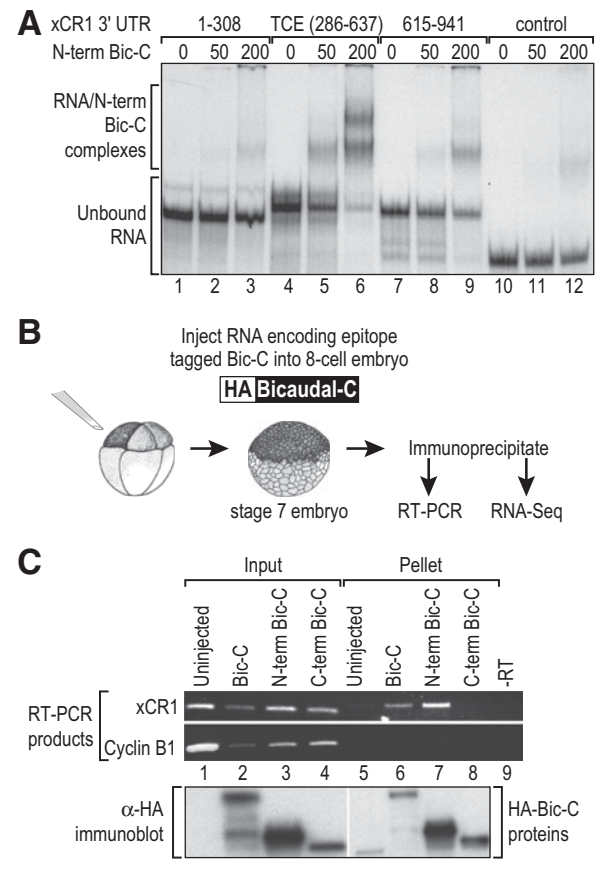

FIGURE 3. The N-terminal region of Bic-C specifically binds the TCE region of the XCR1 $3^{\prime}$ UTR that directs translational repression. (A) Radiolabeled RNAs were mixed with 0, 50, and $200 \mathrm{nM}$ GST-N-term Bic-C protein, and binding was analyzed by native gel electrophoresis. The 1-308, TCE (286-637), and 615-941 radiolabeled RNAs were derived from the xCR1 3' UTR (see Fig. 2). The negative control RNA was derived from the pSTBlue plasmid. (B) Xenopus embryos injected with mRNAs encoding HA-tagged versions of Bic-C, the N-terminal half of Bic-C, or the $\mathrm{C}$-terminal half of Bic-C. The Bic-C proteins were immunoprecipitated from blastula stage injected embryos with aHA antibodies, and the mRNAs present were analyzed using RTPCR and RNA-seq. $(C)$ The presence of the xCR1 and cyclinB1 mRNAs in the input and pellet fractions as assayed with RT-PCR. The input samples were unfractionated extract, and the pellet samples were the HA immunoprecipitates. Proteins from the input and pellet samples were analyzed by immunoblotting and the HA antibody (lower panel). The low molecular weight species detected in the uninjected sample (lane 5) is a cross-reacting species with the HA antibody. protein's RNA binding function and is capable of binding specifically to a region of the XCR1 3' UTR sufficient for translational repression.

\section{Bicaudal-C binds XCR1 mRNA in vivo}

If $\mathrm{Bic}-\mathrm{C}$ mediates repression in vivo, then ectopic Bic- $\mathrm{C}$ should bind the endogenous xCR1 mRNA in animal cells. To test this prediction, we expressed HA-tagged full-length Bic-C (HA-Bic-C) and the N-terminal (N-term) and C-terminal (C-term) halves of Bic-C in embryos by injecting mRNAs encoding the various Bic-C proteins into the animal cells of an eight-cell embryo, The tagged Bic-C proteins were immunoprecipitated from Stage 7 embryos ( $\sim 256$ cells $)$ with an anti-HA antibody (Fig. 3B). The presence of specific mRNAs in the immunoprecipitates (pellet fraction) was assayed using RT-PCR (Fig. 3C; Cooke et al. 2010). Endogenous xCR1 mRNA was coimmunoprecipitated by HA-Bic-C, while the highly abundant cyclin B1 mRNA was not (Fig. 3C). Moreover, the $\mathrm{N}$-terminal half of Bic-C efficiently bound the $\mathrm{xCR} 1 \mathrm{mRNA}$, while the C-terminal half did not. Our results are consistent with recent studies in mammalian kidney cells that found that the N-terminal domain of human Bic- $\mathrm{C}$ was also sufficient to bind the adenylate cyclase6 mRNA target (Piazzon et al. 2012). Thus, Bic-C associated specifically with the endogenous $\mathrm{xCR} 1 \mathrm{mRNA}$ in embryos, consistent with its role as a direct translational repressor. The N-terminal half of the protein was sufficient for binding to a specific RNA substrate in vivo as well as in vitro.

\section{Identification of Bic-C mRNA targets}

To identify additional mRNA targets of Bic-C without bias, we immunoprecipitated Bic-C and identified associated mRNAs by deep sequencing (Fig. 3B). The RNAs from an immunoprecipitation of embryos not expressing HA-Bic-C was used as a negative control. Sequence reads were mapped to reference transcripts from the Xenopus laevis UniGene contigs and transcript abundances were estimated for each RNA-seq sample using RSEM (Li and Dewey 2011). Statistical analysis of the RNA sequences from the Bic-C immunoprecipitates compared to the control sample identified 62 mRNAs enriched in the Bic-C sample using a false discovery rate cutoff of 0.05 (Supplemental Table 1). The enrichment of specific mRNAs in the Bic-C immunoprecipitate was confirmed by assaying for individual mRNAs using quantitative RT-PCR (Supplemental Fig. 3).

In addition to the expected xCR1 mRNA, many of the mRNAs associated with Bic-C encode proteins that function in developmentally relevant pathways. For example, the Dpy30 mRNA encodes a histone methyltransferase important for cell fate decisions in ES cells (Jiang et al. 2011), while the BCCIP mRNA encodes a protein that guides progenitor cells in neural development (Huang et al. 2012). Furthermore, several of the Bic-C mRNA targets encode proteins implicated in 
Nodal/TGF $\beta$ signaling; Smad4b (Chang et al. 2006) is a pathway transcription factor, Oct25 is a transcription factor antagonist (Cao et al. 2008), and Coco is a secreted signaling antagonist (Bell et al. 2003; Vonica and Brivanlou 2007; Supplemental Table 2). These results suggest that Bic-C regulates multiple maternal mRNAs that encode critical proteins important for early vertebrate development.

If the mRNAs we had identified were bona fide targets in vivo, then they were likely to be repressed by Bic-C in the ectopic repression assay (Fig. 1A). Therefore, the $3^{\prime}$ UTRs from 14 different Bic-C-HA-associated mRNAs were used to generate luciferase reporter mRNAs. Since the $3^{\prime}$ UTRs of most Xenopus mRNAs are poorly characterized, we chose 14 potential Bic-C mRNA targets based primarily on the availability of $3^{\prime}$-UTR sequence information for cloning. Bic-C repression of these reporter mRNAs was assessed using the ectopic Bic-C expression animal cap assay described above (Fig. 1A). Each of the 14 reporters was repressed by Bic-C, though the extent of repression varied from $25 \%$ to $90 \%$ (Fig. 4A). These data indicate that Bic-C association with these mRNAs was biologically relevant to their translational regulation.

The normal mechanism of $\mathrm{xCR} 1$ translational repression is vegetal cell-specific, consistent with Bic-C protein's localization to these cells. While the additional Bic-C mRNA targets identified above were isolated in animal cell experiments, another prediction was that their $3^{\prime}$ UTRs would direct vegetal cell-specific repression. We tested this prediction by analyzing the repression guided by the $3^{\prime}$ UTRs of the Coco and Spin reporter mRNAs in vegetal cells (Fig. 4B). These $3^{\prime}$ UTRs were chosen for analysis because they were efficiently repressed by ectopic Bic-C in animal cells (Fig. 4A). Reporter mRNAs containing 3' UTRs from the Coco and Spin mRNAs were repressed in vegetal cells as predicted for bona fide regulatory targets of Bic-C translational repression (Fig. 4C).

\section{DISCUSSION}

Bic-C protein is responsible for spatial regulation of $\mathrm{xCR} 1$ mRNA in the Xenopus embryo. Its ectopic presence in the an- imal hemisphere is sufficient to repress an mRNA bearing the 3'-UTR elements of xCR1 mRNA. Further, Bic-C associates with a battery of other mRNAs and mediates regulation of reporters through their $3^{\prime}$ UTRs. Many of the target mRNAs have vital roles in development, including the Nodal pathway in which $\mathrm{xCR} 1$ protein participates. We suggest that maternal Bic-C helps generate embryonic polarities and influence cellfate decisions during early vertebrate embryogenesis by direct translational regulation of mRNAs that encode cell-fate determinants.

The conclusion that Bic-C is the difference between animal and vegetal cells responsible for the differential translation of xCR1 mRNA is supported by four lines of evidence. First, Bic-C protein is confined to vegetal cells through localization of its mRNA (Wessely and De Robertis 2000). Second, ectopic expression of Bic-C in animal cells was sufficient to repress a reporter mRNA bearing the regulatory region in the $3^{\prime}$ UTR that is responsible for vegetal repression. Third, Bic-C-mediated repression was dependent on the $5^{\prime}$ cap and initiation factors, as is vegetal cell-specific repression. Fourth, the N-terminal region of Bic-C, containing multiple $\mathrm{KH}$ domains, associated with endogenous $\mathrm{xCR} 1$ mRNA in vivo and bound with specificity to the relevant control element (TCE) within the xCR1 mRNA $3^{\prime}$ UTR in vitro. Since the mere presence of Bic-C in animal cells is sufficient to drive repression, we conclude that Bic-C protein is the only component missing from animal cap cells necessary for vegetal cell-specific repression.

Repression requires two distinct domains in Bic-C. The Nterminal domain is sufficient for specific binding to $\mathrm{xCR} 1$ mRNA but insufficient for repression; conversely, the C-terminal domain is sufficient for repression but fails to bind the RNA. The N-terminal region contains multiple $\mathrm{KH}$ domains, which likely mediate interactions with the regulatory element. The C-terminal region contains a SAM domain, a protein-protein interaction module required for Bic-C's association with RNA granules (P-bodies) (Maisonneuve et al. 2009; Tran et al. 2010). However, the SAM domain was neither sufficient nor essential for Bic-C-mediated repression,
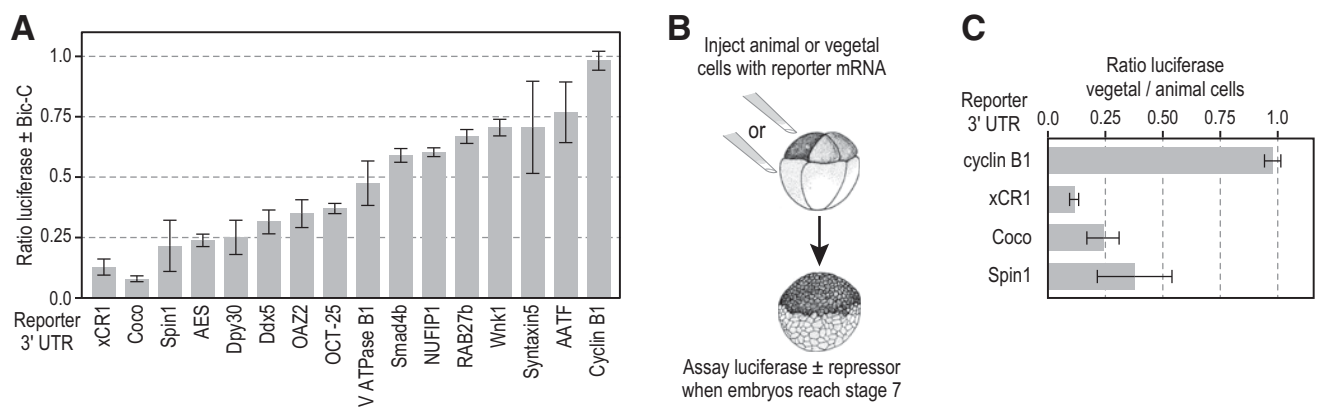

FIGURE 4. Identification of Bicaudal-C-regulated mRNAs. (A) Reporter mRNAs created with the $3^{\prime}$ UTRs of 14 different Bic-C-associated mRNAs identified by RIP-seq were assayed as described in Figure 1A. Reporter mRNAs containing the xCR1 TCE and the cyclin B1 3' UTR serve as positive and negative controls, respectively. $(B, C)$ Diagram of vegetal cell-specific repression assay (Zhang et al. 2009). Reporter mRNAs are injected into animal cells or vegetal cells of separate eight-cell embryos. When embryos reach stage 7, luciferase activity is assayed and the ratio in vegetal cells vs. animal cells calculated. 
though it did enhance that activity. Identification of the key region responsible for repression is now critical.

Recent studies in mammalian kidney cells suggest that Bic-C repression involves miRNAs through an unknown mechanism (Tran et al. 2010; Piazzon et al. 2012). However, miRNA-mediated repression is deficient in Xenopus embryos until after the activation of zygotic transcription, when Argonaute protein first appears (Lund et al. 2011). Thus, Bic-C activity in the early stages of development is likely miRNA-independent.

Through immunoprecipitation and deep sequencing, we identified multiple putative mRNAs controlled by Bic-C. Several targets were sensitive to Bic-C-mediated repression in the animal cell assay, and at least two, Coco and Spin1, were robustly repressed in vegetal cells. We propose that Bic-C acts in a post-transcriptional regulatory network that establishes the proper balance of proteins in the embryo essential for normal development. While its precise role(s) remains to be determined, our findings suggest important roles in Nodal signaling.

Cripto proteins were originally discovered as Nodal/TGF $\beta$ pathway components (Ding et al. 1998; Gritsman et al. 1999; Schier 2009). In addition to xCR1, several other putative BicC mRNA targets identified in this study are strongly implicated in Nodal signaling (Supplemental Table 2). However, the group of mRNAs encodes both activators (e.g., Smad4b) and antagonists (e.g., Coco) of Nodal signaling, indicating that Bic-C's influence on signaling by this pathway may be complex. Bic-C also may influence development through control of other pathways. For example, while Cripto proteins such as $\mathrm{xCR} 1$ have been traditionally viewed as exclusive components of Nodal/TGF $\beta$ signaling (Schier 2009), other evidence indicates that they also function in other signaling processes, such as the Wnt pathway (Tao et al. 2005; Nagaoka et al. 2012, 2013). Our results connecting xCR1 and Bic-C in Xenopus embryos raise the possibility that analogous regulation occurs in mammalian somatic cells. Indeed, Bic-C's inhibition of Wnt signaling may require repression of mammalian Cripto mRNA (Maisonneuve et al. 2009).

Our study focused on the role of Bic-C present in the maternal embryo, prior to the onset of zygotic transcription. In later mammalian development and in adults, Bic-C continues to be critical, influencing specific organs, particularly the kidney (Maisonneuve et al. 2009; Tran et al. 2010). Some targets regulated in the embryo, identified here, may be controlled by Bic-C in later development as well. For example, Coco mRNA (called Dand5 in mouse and Cerl2 in humans) controls positioning of the visceral organs within the body cavity. Loss-offunction alleles of Coco and Bic-C cause similar defects in organ positioning, raising the possibility that Bic-C may control Coco in somatic cells. Similarly, multiple other targets of BicCidentified here (e.g., the mRNAs encoding the Wnk1 and VATPase B1 proteins) are critical for normal kidney development and function (Karet et al. 1999a,b; Arroyo and Gamba 2012; Naguro et al. 2012). Thus, our findings and the recent demonstration that adenylate cyclase6 mRNA is a Bic-C target in kidney cells (Piazzon et al. 2012) support the idea that translational control by Bic-C plays a key role in renal development and point to relevant mRNA targets worth further inquiry. In other systems, single regulatory proteins often mediate control of hundreds of mRNAs with related functions (Gerber et al. 2004; Ule and Darnell 2006; Richter 2007; Kershner and Kimble 2010). Our results reveal that Bic-C may form an analogous hub during vertebrate development.

\section{MATERIALS AND METHODS}

\section{Luciferase reporter mRNA plasmids and mRNA synthesis}

Firefly luciferase reporter mRNAs were generated that contained different segments of the xCR1 mRNA 3' UTR and other 3' UTRs (Sheets et al. 1994; Fritz and Sheets 2001; Zhang et al. 2009). See Supplemental Methods.

\section{mRNA injections and luciferase assays}

Reporter mRNAs were injected into either the animal cells or vegetal cells of eight-cell embryos. When injected embryos reached stage 7 , extracts were prepared and analyzed for luciferase activity (Sheets et al. 1994; Fritz and Sheets 2001; Zhang et al. 2009).

\section{RNA blot hybridization}

Total RNA from embryos injected with reporter mRNAs was analyzed by RNA blot hybridization (Sheets et al. 1994; Zhang et al. 2009) using a radiolabeled probe to detect the firefly luciferase mRNA.

\section{Electrophoretic mobility assays}

Recombinant GST-N-term Bic-C fusion protein (residues 1-506) was expressed and purified as described (Hou et al. 2005, 2009). RNA substrates were generated by in vitro transcription with ${ }^{32} \mathrm{P}$ UTP. The RNAs encoding the xCR1 3'-UTR fragments 1-308, TCE (previously referred to as Mut2), and 615-941 were derived from the xCR1 3' UTR (Zhang et al. 2009). The NEG control RNA (261 nt) was generated from the pSTBlue-1 plasmid. Binding reactions $(20 \mu \mathrm{L})$ contained GST-N-term Bic-C protein (either 0, 50, or $200 \mathrm{nM}$ ), $10 \mathrm{mM}$ Hepes $\mathrm{pH}$ 8.0, $1 \mathrm{mM}$ EDTA, $50 \mathrm{mM}$ $\mathrm{KCl}, 0.02 \%$ Tween-20, $0.2 \mathrm{mg} / \mathrm{mL}$ yeast tRNA, $100 \mu \mathrm{g} / \mathrm{mL}$ BSA, 2 $\mathrm{mM}$ DTT, and $0.5 \mathrm{nM}$ RNA. Reaction products were analyzed on $4 \%(1 \times \mathrm{TBE})$ native polyacrylamide gels.

\section{Immunoblotting}

Immunoblotting was done as described (Kwak et al. 2008) using mouse monoclonal anti-HA-tag antibody and anti-Actin antibody. 


\section{Tethered function assays}

Tethered function assays were performed in Xenopus oocytes as described (Coller et al. 1998; Coller and Wickens 2002; Cooke et al. 2010). Information on MS2 fusions is found in Supplemental Methods.

\section{Q-PCR}

Quantitative PCR to analyze mRNAs associated with Bic- $\mathrm{C}$ was performed as described (Park et al. 2011). Information on primers is found in Supplemental Methods.

\section{Immunoprecipitations}

Xenopus embryos were injected with mRNA encoding HA-Bic-C (full length Bic-C), HA-N-term Bic-C (the N-terminal half of BicC, aa 1-506), or HA-C-term Bic-C (the C-terminal half of Bic-C, aa 507-963). Blastula stage (st.7) injected embryos were lysed in $100 \mu \mathrm{L}$ of TNMEN-150 buffer (Cooke et al. 2010). The lysate was centrifuged $\left(4^{\circ} \mathrm{C}, 10 \mathrm{~min}\right.$ at $\left.5000 \mathrm{rpm}\right)$ and the supernatant incubated with $\alpha$-HA antibody coupled to protein-G agarose $\left(2 \mathrm{~h}, 4^{\circ} \mathrm{C}\right)$. The beads were collected ( $1 \mathrm{~min}, 3000 \mathrm{rpm}$ ) and washed $4 \times$ in $1 \mathrm{~mL}$ TNMEN 150 buffer. For each wash, the beads were incubated in buffer at $4^{\circ} \mathrm{C}$ for $5 \mathrm{~min}$, spun at $3000 \mathrm{rpm}$ for $1 \mathrm{~min}$, and supernatant removed. RNA and protein were isolated from the washed beads for analysis.

\section{Construction of RNA-seq libraries and RNA-seq}

Immunoprecipitated RNA and a total RNA control were submitted to the University of Wisconsin-Madison Biotechnology Center for RNA-seq library preparation and sequencing. See Supplemental Methods for specifics of library preparation and sequencing.

\section{RNA-seq data analysis}

Transcript abundances were estimated for each RNA-seq sample using RSEM (v1.0.2.5) (Hou et al. 2009; Li and Dewey 2011). RSEM was provided with the $X$. laevis UniGene contigs (Wheeler et al. 2003) to use as reference sequences. The read counts estimated for each transcript by RSEM were rounded and then given as input to the R package DESeq (v1.0.6) for differential expression analysis. BIC-C targets were identified as the transcripts that had positive logfold change and FDR less than 0.05 in a comparison of the HA-pellet to UN-pellet samples.

\section{SUPPLEMENTAL MATERIAL}

Supplemental material is available for this article.

\section{ACKNOWLEDGMENTS}

We thank Catherine Fox for her insightful and useful comments. We also thank Laura Vanderploeg for preparing figures and Susanne Blaser Imboden for technical assistance. E. De Robertis and Mary Lou King kindly supplied reagents. This work was supported by NSF grant 1050395 (M.D.S.), NIH grants HG005232 (C.N.D.),
GM31892, and GM50942 (M.W.), NIH training grant T32 GM07215 (A.C.), and an Advanced Opportunity Fellowship from the University of Wisconsin-Madison (A.C.).

Received July 16, 2013; accepted July 25, 2013.

\section{REFERENCES}

Arroyo JP, Gamba G. 2012. Advances in WNK signaling of salt and potassium metabolism: Clinical implications. Am J Nephrol 35: 379-386.

Bell E, Munoz-Sanjuan I, Altmann CR, Vonica A, Brivanlou AH. 2003. Cell fate specification and competence by Coco, a maternal BMP, TGF $\beta$, and Wnt inhibitor. Development 130: 1381-1389.

Cao Y, Siegel D, Oswald F, Knochel W. 2008. Oct25 represses transcription of nodal/activin target genes by interaction with signal transducers during Xenopus gastrulation. J Biol Chem 283: 3416834177.

Chang C, Brivanlou AH, Harland RM. 2006. Function of the two Xenopus smad4s in early frog development. J Biol Chem 281: 30794-30803.

Chicoine J, Benoit P, Gamberi C, Paliouras M, Simonelig M, Lasko P. 2007. Bicaudal-C recruits CCR4-NOT deadenylase to target mRNAs and regulates oogenesis, cytoskeletal organization, and its own expression. Dev Cell 13: 691-704.

Coller J, Wickens M. 2002. Tethered function assays using $3^{\prime}$ untranslated regions. Methods 26: 142-150.

Coller J, Wickens M. 2007. Tethered function assays: An adaptable approach to study RNA regulatory proteins. Methods Enzymol 429: 299-321.

Coller JM, Gray NK, Wickens MP. 1998. mRNA stabilization by poly(A) binding protein is independent of poly $(\mathrm{A})$ and requires translation. Genes Dev 12: 3226-3235.

Cooke A, Prigge A, Wickens M. 2010. Translational repression by deadenylases. J Biol Chem 285: 28506-28513.

Ding J, Yang L, Yan YT, Chen A, Desai N, Wynshaw-Boris A, Shen MM. 1998. Cripto is required for correct orientation of the anterior-posterior axis in the mouse embryo. Nature 395: 702-707.

Dorey K, Hill CS. 2006. A novel Cripto-related protein reveals an essential role for EGF-CFCs in Nodal signalling in Xenopus embryos. Dev Biol 292: 303-316.

Fritz BR, Sheets MD. 2001. Regulation of the mRNAs encoding proteins of the BMP signaling pathway during the maternal stages of Xenopus development. Dev Biol 236: 230-243.

Gamberi C, Lasko P. 2012. The bic-C family of developmental translational regulators. Comp Funct Genomics 2012: 141386.

Gerber AP, Herschlag D, Brown PO. 2004. Extensive association of functionally and cytotopically related mRNAs with Puf family RNA-binding proteins in yeast. PLoS Biol 2: E79.

Gritsman K, Zhang J, Cheng S, Heckscher E, Talbot WS, Schier AF. 1999. The EGF-CFC protein one-eyed pinhead is essential for nodal signaling. Cell 97: 121-132.

Hou Z, Bernstein DA, Fox CA, Keck JL. 2005. Structural basis of the Sir1-origin recognition complex interaction in transcriptional silencing. Proc Natl Acad Sci 102: 8489-8494.

Hou Z, Danzer JR, Mendoza L, Bose ME, Muller U, Williams B, Fox CA. 2009. Phylogenetic conservation and homology modeling help reveal a novel domain within the budding yeast heterochromatin protein Sir1. Mol Cell Biol 29: 687-702.

Huang YY, Lu H, Liu S, Droz-Rosario R, Shen Z. 2012. Requirement of mouse BCCIP for neural development and progenitor proliferation. Plos One 7: e30638.

Jiang H, Shukla A, Wang X, Chen WY, Bernstein BE, Roeder RG. 2011. Role for Dpy-30 in ES cell-fate specification by regulation of H3K4 methylation within bivalent domains. Cell 144: 513-525.

Karet FE, Finberg KE, Nayir A, Bakkaloglu A, Ozen S, Hulton SA, Sanjad SA, Al-Sabban EA, Medina JF, Lifton RP. 1999a. Localization of a gene for autosomal recessive distal renal tubular 
acidosis with normal hearing ( $r d R T A 2)$ to 7q33-34. Am J Hum Genet 65: 1656-1665.

Karet FE, Finberg KE, Nelson RD, Nayir A, Mocan H, Sanjad SA, Rodriguez-Soriano J, Santos F, Cremers CW, Di Pietro A, et al. 1999b. Mutations in the gene encoding B1 subunit of H+-ATPase cause renal tubular acidosis with sensorineural deafness. Nat Genet 21: 84-90.

Kershner AM, Kimble J. 2010. Genome-wide analysis of mRNA targets for Caenorhabditis elegans FBF, a conserved stem cell regulator. Proc Natl Acad Sci 107: 3936-3941.

Kieft JS. 2008. Viral IRES RNA structures and ribosome interactions. Trends Biochem Sci 33: 274-283.

Kwak JE, Drier E, Barbee SA, Ramaswami M, Yin JC, Wickens M. 2008. GLD2 poly(A) polymerase is required for long-term memory. Proc Natl Acad Sci 105: 14644-14649.

Li B, Dewey CN. 2011. RSEM: Accurate transcript quantification from RNA-Seq data with or without a reference genome. $B M C$ Bioinformatics 12: 323.

Lund E, Sheets MD, Imboden SB, Dahlberg JE. 2011. Limiting Ago protein restricts RNAi and microRNA biogenesis during early development in Xenopus laevis. Genes Dev 25: 1121-1131.

Maisonneuve C, Guilleret I, Vick P, Weber T, Andre P, Beyer T, Blum M, Constam DB. 2009. Bicaudal C, a novel regulator of Dvl signaling abutting RNA-processing bodies, controls cilia orientation and leftward flow. Development 136: 3019-3030.

Mosquera L, Forristall C, Zhou Y, King ML. 1993. A mRNA localized to the vegetal cortex of Xenopus oocytes encodes a protein with a nanos-like zinc finger domain. Development 117: 377-386.

Muller-McNicoll M, Neugebauer KM. 2013. How cells get the message: Dynamic assembly and function of mRNA-protein complexes. Nat Rev Genet 14: 275-287.

Nagaoka T, Karasawa H, Castro NP, Rangel MC, Salomon DS, Bianco C. 2012. An evolving web of signaling networks regulated by Cripto- 1 . Growth Factors 30: 13-21.

Nagaoka T, Karasawa H, Turbyville T, Rangel MC, Castro NP, Gonzales M, Baker A, Seno M, Lockett S, Greer YE, et al. 2013. Cripto-1 enhances the canonical Wnt/ $\beta$-catenin signaling pathway by binding to LRP5 and LRP6 co-receptors. Cell Signal 25: 178-189.

Naguro I, Umeda T, Kobayashi Y, Maruyama J, Hattori K, Shimizu Y, Kataoka K, Kim-Mitsuyama S, Uchida S, Vandewalle A, et al. 2012. ASK3 responds to osmotic stress and regulates blood pressure by suppressing WNK1-SPAK/OSR1 signaling in the kidney. Nat Commun 3: 1285.

Otero LJ, Devaux A, Standart N. 2001. A 250-nucleotide UA-rich element in the $3^{\prime}$ untranslated region of Xenopus laevis Vg1 mRNA represses translation both in vivo and in vitro. RNA 7: 1753-1767.
Park S, Patterson EE, Cobb J, Audhya A, Gartenberg MR, Fox CA. 2011. Palmitoylation controls the dynamics of budding-yeast heterochromatin via the telomere-binding protein Rif1. Proc Natl Acad Sci 108: 14572-14577.

Piazzon N, Maisonneuve C, Guilleret I, Rotman S, Constam DB. 2012. Bicc1 links the regulation of cAMP signaling in polycystic kidneys to microRNA-induced gene silencing. J Mol Cell Biol 4: 398-408.

Richter JD. 2007. CPEB: A life in translation. Trends Biochem Sci 32: 279-285.

Saffman EE, Styhler S, Rother K, Li W, Richard S, Lasko P. 1998. Premature translation of oskar in oocytes lacking the RNA-binding protein bicaudal-C. Mol Cell Biol 18: 4855-4862.

Schier AF. 2009. Nodal morphogens. Cold Spring Harb Perspect Biol 1: a003459.

Sheets MD, Fox CA, Hunt T, Vande Woude G, Wickens M. 1994. The $3^{\prime}$-untranslated regions of c-mos and cyclin mRNAs stimulate translation by regulating cytoplasmic polyadenylation. Genes Dev 8: 926-938.

Tao Q, Yokota C, Puck H, Kofron M, Birsoy B, Yan D, Asashima M, Wylie CC, Lin X, Heasman J. 2005. Maternal wnt11 activates the canonical wnt signaling pathway required for axis formation in Xenopus embryos. Cell 120: 857-871.

Tran U, Zakin L, Schweickert A, Agrawal R, Doger R, Blum M, De Robertis EM, Wessely O. 2010. The RNA-binding protein bicaudal $\mathrm{C}$ regulates polycystin 2 in the kidney by antagonizing miR-17 activity. Development 137: 1107-1116.

Ule J, Darnell RB. 2006. RNA binding proteins and the regulation of neuronal synaptic plasticity. Curr Opin Neurobiol 16: 102-110.

Valverde R, Edwards L, Regan L. 2008. Structure and function of KH domains. FEBS J 275: 2712-2726.

Vonica A, Brivanlou AH. 2007. The left-right axis is regulated by the interplay of Coco, Xnrl and derriere in Xenopus embryos. Dev Biol 303: 281-294.

Wessely O, De Robertis EM. 2000. The Xenopus homologue of Bicaudal$C$ is a localized maternal mRNA that can induce endoderm formation. Development 127: 2053-2062.

Wheeler DL, Church DM, Federhen S, Lash AE, Madden TL, Pontius JU, Schuler GD, Schriml LM, Sequeira E, Tatusova TA, et al. 2003. Database resources of the National Center for Biotechnology. Nucleic Acids Res 31: 28-33.

Yabe S, Tanegashima K, Haramoto Y, Takahashi S, Fujii T, Kozuma S, Taketani Y, Asashima M. 2003. FRL-1, a member of the EGF-CFC family, is essential for neural differentiation in Xenopus early development. Development 130: 2071-2081.

Zhang Y, Forinash KD, McGivern J, Fritz B, Dorey K, Sheets MD. 2009. Spatially restricted translation of the xCR1 mRNA in Xenopus embryos. Mol Cell Biol 29: 3791-3802. 

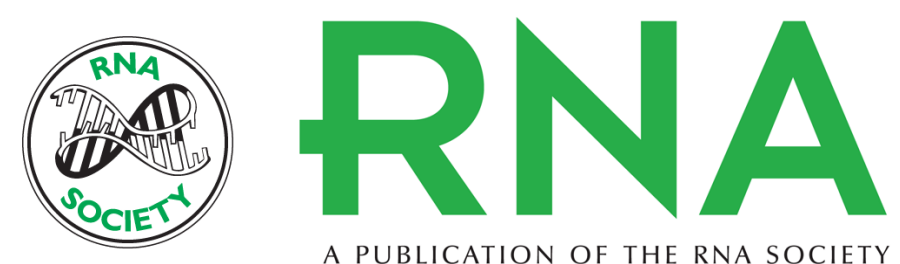

A PUBLICATION OF THE RNA SOCIETY

\section{Bicaudal-C spatially controls translation of vertebrate maternal mRNAs}

Yan Zhang, Amy Cooke, Sookhee Park, et al.

RNA 2013 19: 1575-1582 originally published online September 23, 2013

Access the most recent version at doi:10.1261/rna.041665.113

\section{Supplemental http://rnajournal.cshlp.org/content/suppl/2013/08/08/rna.041665.113.DC1 \\ Material}

References This article cites 48 articles, 21 of which can be accessed free at: http://rnajournal.cshlp.org/content/19/11/1575.full.html\#ref-list-1

Creative This article is distributed exclusively by the RNA Society for the first 12 months after the Commons full-issue publication date (see http://rnajournal.cshlp.org/site/misc/terms.xhtml). After 12

License months, it is available under a Creative Commons License (Attribution-NonCommercial 3.0 Unported), as described at http://creativecommons.org/licenses/by-nc/3.0/.

Email Alerting
Service

Receive free email alerts when new articles cite this article - sign up in the box at the top right corner of the article or click here.

To subscribe to RNA go to:

http://rnajournal.cshlp.org/subscriptions 